\title{
Locusts (Acrididae) Diversity in Gunung Bunder Forest Park
}

\author{
Sri Rahayu*, Sulistiyawati \\ Biology Education Department, Faculty of Science and Technology, UIN Sunan Kalijaga Yogyakarta \\ J1. Marsda Adisucipto No 1 Yogyakarta 55281, Indonesia. Tel. +62-274-540971, Fax. +62-274-519739. \\ *Email: sri.rahayu527@gmail.com
}

\begin{abstract}
Rahayu S, Sulistiyawati. 2017. Locusts (Acrididae) Diversity in Gunung Bunder Forest Park. Proc Internat Conf Sci Engin 1: 49-53. The aim of this study was to know the grasshopper diversity in Gunung Bunder Forest Park. Sampling plots were done by purposive sampling method. Grasshoppers were catched by a sweeping net and glue trapping. The result of the research were as follows: grasshopper diversity $\left(H^{\prime}=1.32\right)$, the number of individuals $(n=1127)$, dominance index $(\mathrm{D}=0.4)$ and the species evenness index $(\mathrm{E}=0.55)$. Grasshopper species found are Phlaeoba fumosa, Stenocatantops splendens, Stenocatantops angustifrons, Eucoptacra sp., Chondracris rosea, Valanga nigricornis, Leptacris sp., Gastrimargus marmoratus, Trilophidia annulata, Oedaleus infernalis, Oxya japonica and Caryanda spuria.
\end{abstract}

Keywords: Acrididae, Grasshopper, Gunung Bunder Forest Park

\section{INTRODUCTION}

Gunung Bunder Forest Park is located in Desa Bunder, Patuk, Playen, Gunung Gading subdistrict (BKSDA, 2007). The village is in the region of Bunder Stakeholder Forest Resort. Gunung Bunder Forest is located at an altitude of 110 meters to 200 meters above sea level with rainfall of $1,900 \mathrm{~mm} /$ year and the average air temperature is $27,7^{\circ} \mathrm{C}$ (Utami and Indrayani, 2013).

Gunung Bunder Forest Park was production forest that become conservation forest by the Minister of Forestry No. 353/ Menhut-II / 2004 on Function Change of Forest Area Bunder plots 11, 15, 20, 21 and Banaran plots 19, 22, 23, 24 area \pm 617 ha located in Gunung Kidul Regency of Yogyakarta. Special Region into Forest Park (MoF, 2007).

Flora of Bunder Forest are dominated by eucalyptus (Melaleuca leucadendron), acacia (Acacia auriculiformis), mahogany (Swietenia macrophyla), Albizia Buto (Albizia sp), and various agroforestry crops such as breadfruit (Artocarpus cummini), and cashew (Anacardium occidentale).

Bird is the only fauna that have been studied. Grasshoppers (Acrididae) have never studied yet (Haryono, personal communication, March 22, 2016). It is interesting necessary to study the diversity of grasshopper in Gunung Bunder Forest Park.

\section{MATERIALS AND METHODS}

Time and Place of Research

The research were done for 2 months (June-July 2016). The research includes two resort namely Stakeholder Forest Resort Bunder and Resort Stakeholder Forest Banaran.

Equipment and Materials Research
The tools used in data collection is a sweep net, glue trapping, plastic bottle that, small jars, thermohygrometer, lux meter, soil tester, Global Position System (GPS), compass, rope measured length, paper labels, stationery, camera and insect identification book. While the materials used are chloroform $70 \%$ and cotton.

\section{Method of Collecting Data}

Sampling plots were done by purposive sampling method, by selecting four plots which have a different structure vegetation.

Sampling is done by making main transect line with a length of $2000 \mathrm{~m}$ following the path of the trail. Every $20 \mathrm{~m}$ on the main transect perpendicular secondary transects made along $20 \mathrm{~m}$ to the right and to the left. On each transect secondary made observation area with an area of $500 \mathrm{~m} 2(20 \mathrm{mx} 25 \mathrm{~m})$

Grasshoppers were trapped using a sweeping net and glue. Sweeping were carried on at a low herbaceous vegetation, shrubs and grasses by using a sweep net which swung as much as 15 swings and repeated 3 times. Glue method is done to trap locusts seen in high vegetation.

Identification was done based on morphological characteristics and matched with references.

Measurement of abiotic factors include air temperature, air humidity, soil $\mathrm{pH}$ and light intensity. Measurement of temperature and humidity using a thermo-hygrometer, the $\mathrm{pH}$ of the soil using a soil tester and light intensity using a lux meter.

\section{Data Analysis Technique}

a. Species diversity index

To determine the species diversity index, we use Shannon-Wienner formula (Southwood, 1971)

Explanation:

$$
\mathrm{H}^{\prime}=-\Sigma \mathrm{ni} / \mathrm{N} \ln \mathrm{ni} / \mathrm{N}
$$


$\mathrm{H}^{\prime}$ = Shannon Diversity Index-Wienner

$\mathrm{ni}=$ Number of individuals of a species

$\mathrm{N}=$ The total number of individuals arrested

If the value of $\mathrm{H}^{\prime}<1=$ low diversity, $1<\mathrm{H}^{\prime}<3=$ moderate diversity, $\mathrm{H}^{\prime}>3$ = high diversity (Magurran, 1988).

b. Species evenness index $(E)$

Evenness index (Evenness) is calculated by Pielou formulations.

$$
\mathrm{e}=\mathrm{H}^{\prime} / \mathrm{In} \mathrm{S}
$$

Information:

$\mathrm{H}^{\prime}$ = Shannon Diversity Index-Wienner

$\mathrm{S}=$ Number of species

Evenness value ranges between 0 and 1 . A value of 1 if an abundance of each species approximately has uniform number.

\section{c. Relative abundance}

Relative abundance is used to determine the proportion of species abundance. The formula is as follows:

$$
K R=\frac{n i}{N} \times 100 \%
$$

Information:

ni $\quad=$ Number of individuals in the $i$ kind

$\mathrm{N}=$ The total number of individuals

\section{RESULTS AND DISCUSSION}

Based on the results of the study, total locusts traped were 1127 individuals, consist of 12 species belong o seven subfamilies, covering subfamily Acridinae, Hemiacridinae, Catantopinae, Coptacridinae, Cyrtacanthacridinae, Oedipodinae and Oxyinae. Relative density for each species are presented in Table 1 .

Table 1. Grasshopper Species Found in Gunung Bunder Forest Park.

\begin{tabular}{lllll}
\hline No & Subfamily & Species & Number of Individuals & RD $(\%)$ \\
\hline 1. & Acridinae & Phlaeoba Fumosa & 275 & 24.4 \\
2. & Catantopinae & Stenocatantops splendens & 601 & 53.34 \\
& & Stenocatantops angustifrons & 129 & 11.45 \\
3. & Coptacridinae & Eucoptacra sp. & 12 & 1.09 \\
4. & Cyrtacantha-cridinae & Chondracris rosea & 3 & 0.30 \\
& & Valanga nigricornis & 9 & 0.80 \\
5. & Hemiacridinae & Leptacris sp. & 3 & 0.30 \\
6. & Oedipodinae & Gastrimargus marmoratus & 2 & 0.18 \\
& & Trilophidia annulata & 13 & 1.12 \\
& & Oedaleus infernalis & 16 & 1.45 \\
7. & Oxyinae & Oxya japonica & 31 & 2.72 \\
& & Caryanda spuria & 32 & 2,81 \\
\hline
\end{tabular}

Parameters measured in this study included the number of species, the number of idividu, diversity index, dominance and evenness index (Table 2).

Table 2. Parameters Measured in Research.

\begin{tabular}{ll}
\hline Parameter & Amount \\
\hline Number of species / species & 12 \\
number of individuals & 1127 \\
diversity Index & 1.37 \\
dominance & 0.4 \\
Species evenness index & 0.55 \\
\hline
\end{tabular}

Diversity of a living being cannot be separated from environmental inferences. Environmental factors measured in this study include air temperature, humidity, and light intensity (Table 3).
Table 3. Environmental Parameters Measured in the Research.

\begin{tabular}{ll}
\hline Environmental parameters & Value \\
\hline Air temperature & $31.50^{\circ} \mathrm{C}$ \\
Humidity & $83.43 \%$ \\
Soil moisture & $80 \%$ \\
soil pH & 7 \\
Light intensity & 004 lux \\
\hline
\end{tabular}

Based on Table 1 it can be seen that the number of species of grasshoppers (Acrididae) found in Gunung Bunder Forest Park are as many as 12 species belong to 7 subfamily. The most common species found is from the subfamily Oedipodinae, which have three species found. Subfamily Catantopinae, Cyrtacanthacridinae and Oxyinae each have two species. Subfamily Coptacridinae, Hemiacridinae and Acridinae are subfamily with the fewest number of species found, that 
is only one species (Table 1). The high diversity of subfamily Oedipodinae are similar according to the results of research conducted by Raghavender and Vastrad. Oedipodinae is a subfamily that has the highest species richness in forest ecosystems (Raghavender and Vastrad, 2017).

Of the 12 species found, Stenocatantops splendens is the most abundant species, namely 601 individuals (RD $=53.34 \%)($ Table 1). Stenocatantops splendens is widely spread in Asia tropical and sub-tropical (Zhu, et al., 2013). In Indonesia Stenocatntops splendens can be found in Borneo, Java, Maluku, Papua and Sumatra (Sharma, 2012). The high number of Stenocatantops splendens possible because host plants Stenocatantops splendens coverage is very broad. Stenocatantops splendens eat herbaceous plants and grasses (Hsiao, et. Al., 2017). In this study, the intensity for encounter Stenocatantops splendens are very high. Stenocatantops splendens found throughout the hours of observation. Based on the research results by Erniwati (2009), Stenocatantops splendens active from 08:00 to 12:00.

The second highest individual after Stenocatantops splendens is Phlaeoba fumosa namely 275 individuals $(\mathrm{KR}=24.4 \%)$ (Table 1$)$. Sulistiyowati (2015) also report that Phlaeoba fumosa is the species most commonly found. Sharma (2012) also showed that the genus Phlaeoba experienced a population peak in July $(20.97 \%)$ and August (19.47\%). In this month an increase in relative humidity of the soil affects vegetation growth enhancement of plants. According Wilemse (2001), Orthoptera population is closely related to vegetation, because plants are the source of food. Phlaeoba grasshopper host plants such as grasses Fumosa (Hsiao et al., 2017).

Fewest individual found are Gastrimargus marmoratus (Table 1). The low number of individuals found was due to the main habitat is the grasslands. Gastrimargus genus is widely distributed in tropical grasslands of Africa, Asia and Australasia. In addition Gastrimargus marmoratus host range is low. Gastrimargus marmoratus is graminivorous, so only eat the plants of the family of grasses. Gastrimargus prefers moist habitats than Oedaleus, but both are equally genus are graminivorous (Song, 2010).

The lowest individual found is Chondracris rosea (Figure 22) and Leptacris sp which is only 3 individuals (Table 1). The low number of Chondracris rosea found possible because of the lack of host plants at Gunung Bunder Forest Park. The main host of Chondracris rosea is a plant citrus, soybean, cotton, potato, rice, sugar cane and corn. According to Srinivasan and Prabakar (2013), habitat of Chondracris rosea is maize and bananas. Suhail (2001) showed that Chondracris rosea is found in a cornfield. The main host plant Chondracris rosea in Gunung Bunder Forest Park is corn. However, these plants are found only in some plots and its existence depends on the activity of farmers. Chondracris rosea are distribute in China, Java, Philippines, and India. Chondracris rosea perfect green for camouflage with the environment. This locust is able to fly at a distance of 15-20 m, showing reddish wings (Bhowmik, 1986). Chondracris rosea can be found in May to September (Narzari and Sarmah, 2015).

Leptacris $s p$ belong the subfamily Hemiacridinae. This grasshopper insects are polyphagus, which can cause severe damage to almost all types of plants in the world. Hemiacridinae prefer habitats such as tall grass and rice. After eating rice, Hemiacridinae will be moved to the prairie ecosystem and lays eggs in a safe area. In addition to rice plants, the locust also like maize, millet, sugar cane, sorghum and beans (Akhtar et al., 2014). In Gunung Bunder Forest Park, Leptacris sp found in peanuts and corn crops.

Valanga nigricornis The Gunung Bunder Forest Park has a relatively low density that is only $0.8 \%$ (Table 1 ). The number of adult individuals found are 9. The low number of mature individuals is because at the time of observation newly hatched locust were there or still in the nymph stage. Valanga nigricornis population reach its peak in September and April (Atim, 1987). According Wilemse (2001), Orthoptera population is closely related to vegetation, because plants are the source of food.

Table 2 shows the grasshopper diversity in Gunung Bunder Forest Park. The level of diversity is evidenced by the Shannon-Wiener diversity index. According to analysis by the index Shannon-Whinner, locusts in Gunung Bunder Forest Park has a value $\mathrm{H}^{\prime}=1.32$ (Table 2). Values are classified in the medium category. Diversity of species is strongly influenced by temperature, rainfall, humidity, type of soil and vegetation types.

The average temperature of Gunung Bunder Forest Park is $27,7^{\circ} \mathrm{C}$ (Utami and Indrayani, 2013). Temperature alone is not really affect on the abundance and distribution patterns grasshopper (Sharma, 2012). When humidity appropriate, these insects are not so sensitive to extreme temperatures. According to Sharma (2012), the peak of locust populations are at a temperature of $29^{\circ} \mathrm{C}$ with $94 \%$ humidity. In this study, the average temperature from morning until noon reached $31,5^{\circ} \mathrm{C}$ and humidity $83.34 \%$ (Table 3 ). Thus the diversity numbers of locusts in Gunung Bunder Forest Park are not in the high category.

Rainfall Gunung Bunder Forest Park reached 1,900 $\mathrm{mm} /$ year (Utami and Indrayani, 2013). Rainfall affects the growth of plants as a food source of grasshopper (Raghvender and Vastrad, 2017).

Dominance index describes the presence or absence of species that dominate other species. Dominance index values ranged from 0-1 (Juliana et al., 2012). If the dominance index value close to or equal to 1 , then the area is dominated by a particular species, and vice versa. The calculations show that the dominance index value close to 0 (zero), namely 0.4 . (Table 2 ). This shows that there are not dominance species. Number of individuals Oxya japonica, Caryanda spuria, Trilophidia annulata, Eucoptacra sp. and Oedaleus infernalis almost the same. Each of which is 31, 32, 13, 12 and 16 individuals (Table 1). 
Species evenness index illustrates the distribution of species in the community. Evenness index value close to 0 indicates that the distribution of species in a relatively uneven communities, while the evenness index values approaching or equal to 1 indicates that the distribution of species in the community evenly (Wicaksono et al., 2001). Evenness index in this study is worth 0.55 (Table 2). This shows that the spread of individuals of each species in the community is relatively evenly distributed.

\section{CONCLUSIONS}

The species of grasshoppers (Acrididae) found in Forest Park Bunder Gunung namely Phlaeoba Fumosa, Stenocatantops splendens, Stenocatantops angustifrons, Eucoptacra sp., Chondracris rosea, Valanga nigricornis, Leptacris sp., Gastrimargus marmoratus, Trilophidia annulata, Oedaleus infernalis, Oxya japonica and Caryanda spuria. Diversity of grasshoppers (Acrididae) in Gunung Bunder Forest Park was included in the medium category $\left(\mathrm{H}^{\prime}=1.32\right)$.

\section{REFERENCES}

Ahmad, ST and Tajamul, M. 2014. Geomorphological Studies of the Post Embryonic Developmental Stages of Rice Grasshopper, Oxya japonica (Orthoptera: Acrididae). New York Science Journal. 7 (4): 107-111

Akhtar, MH, Nayeem, MR, and Ottoman, MK 2014. Abundance, Distribution and Taxonomic Studies on Hemiacridinae (Acrididae: Acridoidea: Orthoptera) in Uttar Pradesh, India. Journal of Global Biosciences. 3 (6): 910-918

Anamelia, R. 2015. Regeneration Plant at Different Types of stands at 19 RPH Banaran Petak Tahura Bunder. (Final), Forest Management Diploma Program UGM Vocational School, Yogyakarta

Natural Resources Conservation Agency of Yogyakarta. 2007. Statistics Natural Resources Conservation Agency of Yogyakarta. BKSDA Yogyakarta, Yogyakarta

Bhowmik, 1986. HK Grasshopper Fauna of West Bengal India (Orthoptera: Acrididae). Zoological Survey of India, India

Bhusnar, AR 2015. Acridid (Orthoptera) diversity of agriculture ecosystem from Solapur District of Maharashtra, India. Biolife. 3 (2): 461-468

Calpas, J and Johnson, D. 2003. Grasshopper Management. AgriFact. 1-11

Generous, D. 2016. Member of the Order Orthoptera Diversity in cassava fields and teak forests in Kemadang, Gunung Kidul, Yogyakarta and Its Potential as a Source of Food. (Thesis), Gadjah Mada University, Yogyakarta

Gare, KF 2016. Under the Plant Vegetation Analysis in Forest Park Bunder Wonosari, Gunung Kidul Regency of Yogyakarta Special Region. (Thesis), STIPER Agricultural University, Yogyakarta

Erniwati. 2009. Patterns and Diversity Activities Grasshopper (Insecta: Orthoptera) in Taman Mount Ciremai Naasional, Kuningan, West Java. Biological Journal of Indonesia. 5 (3): 319-328

Haryono (Head Coordinator of Forest Park Bunder), personal communication about Forest Park Bunder. Held on March 22, 2016

Hsiao, TF, Yang, J. T and Chen, MY 2017 Grasshopper Mandibles Functional Morphology Adaptation to Food Plants
(Orthoptera: Caelifera) from Subtropical Forest Ecosystem, Central Taiwan. Advances in Entomology. 40-53

Gunung Protocol Public Relations, (December 11th 2012) Soft Opening Tahura. Accessed on June 12, 2016 At 16:21 pm

Magurran, AE 1988. Ecological Diversity and Its Measurement. Chapman and Hill, London

Nair, KSS, 2007. Tropical Forest Insect Pest Ecology, Impact, and Management. Cambridge University Press, Cambridge

Nair, KSS 2000. Insect Pest and Diseases in Indonesian Forests. An Assessment of the Major Threats, Research Efforts and Literature. Bogor: Center for International Forestry Research.

Son, AD (June 20th 2016). BMKG: Year Drought backwards and Dominated Rain Normal. Accessed July 12, 2017 in www.kompas.com

Raghvender, B. and Vastrad, USA, 2017. Changing Scenario of Short Horned Grasshopper Diversity in Agriculture and Forest Ecosystems in Dharwad. Journal of Entomology and Zoology Studies. 5 (2): 268-272

Ramadhani, J. (June 3rd, 2016). Still Would Rain Down on Drought 2016 Beware of Flood and Landslide. Accessed July 12, 2017 in https://m.detik.com

Sands, V E. 2014. Cytology of Malaysian Population Species of Oxya (Acrididae: Oxyinae). International Journal of Cytology, Cytosystematics and Cytogenetics. 40:25-42

Sharma, N., 2012. Acridoidea (Orthoptera: Insecta) Diversity of Dudhwa National Park, Uttar Pradesh, India. Zoological Survey of India. 112 (Part 1): 33-42

Sharma, N. 2012. Population Fluctuation of Grasshopper Fauna in a Field near Kakdwip, Sunderbans, West Bengal. Zoological Survey of India. 3 (Part 3): 27-30

Senthilkumar, N. 2010. Orthopteroids in Kaziranga National Park, Assam, India. Journal of Threatened Taxa. 2 (10): 1227-1231

Song, H. 2010. Density-Dependent Phase Polyphenism in Nonmodel Locust: A Minireview. vol 2011

Southwood, TRE 1971. Ecological Methods, with Particular Reference to the Study of Insect Population. Chapman and Hall Ltd., London

Suhail, A., Suhail, G., and Al-Hariri, MK 2001. Some Acridid Belonging to the subfamily Cyrtachantacridinae Grasshoppers (Acrididae: Orthoptera) from Pakistan. International Journal of Agriculture \& Biology. 3 (1): 43-46

Sulistiyowati, E. 2015. Population Studies Insect Biodiversity Conservation Efforts As Oyo River, at the Tourism Village Bleberan Gunung Kidul. Journal of Biology, University of Andalas. 4 (4): 233-241

Sun, W., Dong, H., Gao, YB., Su, QF., Qian, HT., Bai, HY., Zhang, ZT and Cong, B. 2015. Genetic Variation and Geographic Differentiation among Populations of the Nonmigratory agricultural Pest Oedaleus infernalis (Orthoptera: Acridoidea) in China. Journal of Insect Science. 15 (1): 150

Tajamul, M., Ahmad, ST, Tak, I., and Shafi, J. 2016; Seasonal Variation in the Population of Rice Grasshopper, Oxya japonica (Orthoptera: Acrididae) in the Agricultural Zones of Kashmir Valley. Global Journal of Life and Biological Research. 2 (3): 4-6

Utami, DW and Indryani, R. 2013. Cost Benefit Analysis of Forest Park Development Project (Tahura) Bunder Yogyakarta. Journal of Engineering Pomits. 1: 1-5

Wicaksono, KP, Suryanto, A. Nugroho, A., Nakagoshi, N., and Kurniawan, N. 2011. Insect as Biological Indicator from Protected to the Disturb ladscape in Central Java Indonesia. Journal Agrivita. 33 (1): 75-84

Yuliana, Adiwilaga, EM, Harris, E., and ratiwi, NTM 2012. The relationship between BLAST Phytoplankton the Chemical Physical Parameters in Jakarta Bay waters. Journal Aquatics. 3 (2): $169-179$

Yunus, A. 1964. Insect Pest of Rice in Malaysia. Proceedings of a Symposium at the International Rice Research Institute. The Johns Hopkins Press, Maryland 
Zafar, M. 2015. Prevalence and Economic Importance of Grasshoppers and Their Allies Associated with Foods. Biologia (Pakistan). 61 (1): 189-194
Zhu, DH., Cui, SS., Fan, YS, and Liu, Z. 2013. Adaptive strategies of overwintering adults: Reproductive diapause and mating behavior in a grasshopper, Stenocatantops splendens (Orthoptera: Catantopinae). Insect Science. 20: 235-244 
THIS PAGE INTENTIONALLY LEFT BLANK 